\title{
Selfish genes in race or politics
}

SIR - I hesitate before giving the National Front even a tiny bit more exposure in your pages: I imagine they welcome verbal denunciations, much as, on a larger and a physical scale, they presumably relish a "Smash the Front" march. But a public challenge from Steven Rose has just that touch of insinuation which makes me feel I would be unwise not to respond. He says (Nature 22 January, p.335): "May I suggest that it would be in the public interest that John Maynard Smith and Richard Dawkins should clearly dissociate themselves from the use of their names in support of this neo-Nazi balderdash".

Balderdash is a well chosen word. The extract from New Nation that he quotes is of course obvious balderdash, a travesty of science, in the service of an evil cause. Rose would have had every right to have added, "I told you so." He and his colleagues have long urged that "in due course racists would deploy sociobiology in support of their views". In my naive way, I never believed it possible that such a deployment could seem logical to even the most twisted mind, but perhaps I just lacked Rose's intimate knowledge of how science can be misused for political ends.

The equating of "kinship", in the sense of kin selection, with "ties of race" appears to result from an interesting variant of what $I$ have called the fifth misunderstanding of kin selection'.

Let me pass from this relatively esoteric point to concentrate on the central fallacy of the passage from New Nation that Rose quotes: “. . . our genes don't permit us to live in a Marxist-Rousseauesque egalitarian communist utopian World State of universal altruism. It was an inevitable result of the way evolution works that our genes would not permit us so to live."

The key to the error is to be found in the word "inevitable". I tried to make it clear in The Selfish Gene that " . . . it is a fallacy incidentally a very common one - to suppose that genetically inherited traits are by definition fixed and unmodifiable. Our genes may instruct us to be selfish, but we are not necessarily compelled to obey them all our lives. It may just be more difficult to learn altruism than it would be if we were genetically programmed to be altruistic".

Insofar as my book has any political moral, it is conveyed by the closing sentence: "We, alone on earth, can rebel against the tyranny of the selfish replicators".

There is no evidence that racism is a naturally selected tendency, but just suppose some such evidence were to be discovered. What should be our response to it? The New Nation author presumably would say: Racism is the product of genetic evolution, therefore it is inevitable and desirable, and should be formalized in our political institutions. I would say: Racism is highly undesirable, and if it is indeed the product of genetic evolution this simply means that we should fight all the harder against it. There is a third position, untenable but, nevertheless, commonly held:
Racism is highly undesirable, therefore we cannot allow it to be true that it is the product of genetic evolution. There must be something wrong with the evidence.

What is really wrong with the National Front quotation is not the suggestion that natural selection favoured the evolution of a tendency to be selfish and even racist. What I object to is the suggestion that if such tendencies had evolved they would be inevitable and ineradicable: the suggestion that we are stuck with our biological nature and can't change it. It is this that is the real balderdash, but where on earth did the myth of the inevitability of genetic effects come from? Is it just a layman's fallacy, or are there influential professional biologists putting it about?

Consider the following passage from Rose's ${ }^{2}$ review of E.O. Wilson's On Human Nature: ". . although he does not go as far as Richard Dawkins . . . in proposing sexlinked genes for "philandering", for Wilson human males have a genetic tendency towards polygyny, females towards constancy (don't blame your mates for sleeping around, ladies; it's not their fault they are genetically programmed)".

We may pass quickly over the somewhat free interpretation of my book. "Philanderer males" were not humans, they were hypothetical animals postulated as part of an elementary mathematical model, and in any case the computer simulation which I described ended up with the philanderers slightly outnumbered by "faithful" males.

The serious point I want to make arises out of Rose's amusing remark about ladies not blaming their mates. Just suppose it were shown that "human males have a genetic tendency towards polygyny, females towards constancy", what on earth would that have to do with concepts like "blame" and "fault"? Everybody knows that most healthy humans of both sexes have strong sexual desires which are not always strictly monogamous in aim, and many humans nevertheless enter into voluntary contracts of sexual fidelity, with some at least momentary intention of overcoming their polygamous tendencies. Many even succeed in this.

Depending on our philosophical position with respect to "free will", on the nature of the personal relationships concerned, and on the form of the contract entered into, words like "blame" and "fault" may or may not seem appropriate. But whether or not they are appropriate will not be altered one whit by anything that geneticists may ever discover. If sexual desire is strong or weak, it is so whether or not we label it genetically determined.

The same goes for racial prejudice. Whether it is eradicable or not is a serious question, but the consideration of whether it is "genetic" has no bearing on the matter. Rose may have forgotten the difference between "sex-linked" and "sex-limited" (see quotation above), but he will certainly recall that warhorse of the genetics textbooks, phenylketonuria.

This serious disease, caused by a single recessive gene, is easily cured by rearing the child on a special diet: an "environmental" cure for a genetic disease. If racism should turn out to be a genetically determined disease, I see no reason why it, too, should not be easily cured by suitable rearing conditions. And if it is not easily cured by educational means, exactly the same might be true of an acquired prejudice, say a prejudice that one has been taught during some critical years of early life. There is nothing particularly irrevocable about genetic effects on development, as compared with non-genetic effects.

How Steven Rose and the spokesmen of the National Front came to share their fatalistic views on the inevitability of genetic determination I cannot guess, unless it has something to do with the fact that "historical inevitability" is as dear to the Marxist heart as the related concept of "destiny" is to the Nazi one. In their biological manifestations, at least, the two concepts are as fatuous as each other.

But let me sound another note that may strike a chord in Rose's heart, a note of pure political expediency. If a scientific theory, $\mathrm{X}$, about the nature of man, could have evil human consequences, we may hope that $\mathrm{X}$ will turn out to be false, but we would be unwise to take our stand purely on our hope that it is false. After all, it may just turn out to be true, and then we are left helpless and with our guard down. It is much wiser to say: "I don't think $\mathrm{X}$ is scientifically valid, but even if it is, so what?"'

This message is nowhere more important than in our dealings with the other controversy mentioned in Rose's letter, the race/IQ controversy. As Stephen Jay Gould ${ }^{3}$ puts it with his customary cogency: "I do not claim that intelligence, however defined, has no genetic basis -1 regard it as trivially true, uninteresting, and unimportant that it does ... It is just as likely that blacks have a genetic advantage over whites. And, either way, it doesn't matter a damn",

In the aftermath of Mrs Thatcher's electoral victory in 1979 Steven Rose wrote ${ }^{4}: "$. . . the switch in scientific fashion, if only from group to kin selection models in evolutionary theory, will come to be seen as part of the tide which has rolled the Thatcherites and their concept of a fixed, nineteenth century competitive and xenophobic human nature into power."

The theory of kin selection is logically entailed by the now virtually undisputed neoDarwinian theory itself. It explains things that have been going on in the world for a thousand million years, and that will go on after our species is long extinct. Versions of it probably hold sway in uncountable islands of life all over the universe. It is annoying to find this elegant and important theory being dragged down to the ephemeral level of human politics, and parochial British politics at that. It seems that the National Front are not alone responsible for this.

RI(HARI) DAWKINS

New College,

Oxford, UK

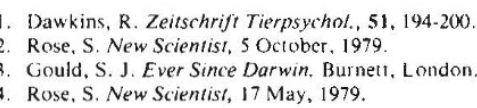

